\title{
POGINGEN TOT OPRICHTING VAN EENE CIRCULATIEBANK IN SURINAME (1849-1864)
}

STICHTING VAN DE SURINAAMSCHE BANK

DOOR

\section{J. VAN ETTINGER}

In Januari 1925 is het 60 -jarig bestaan van de circulatiebank van Suriname, de te Amsterdam gevestigde Surinaamsche Bank, herdacht. In de groote pers en de financieele bladen werd aan bedoeld jubileum slechts weinig aandacht geschonken. Alleen de Nieuwe Financier en Kapitalist wijdde in haar nummer van 25 Januari 1925 een hoofdartikel aan genoemde bankinstelling $\left.{ }^{1}\right)$. Noch in dit hoofdartikel noch in het verslag van De Surinaamsche Bank over 1925, waarin uiteraard het jubileum wordt herdacht (bldz. 1 tot en met 3), wordt er evenwel met een woord over gerept, hoe de oprichting van de Surinaamsche circulatiebank zich heeft toegedragen, hoe de voorgeschiedenis der instelling is geweest.

Daar ook in het bekende werk van Mr. G. J. Fabius, het „Bankwezen in Nederlandsch-West-Indië”, niets omtrent deze aangelegenheid vermeld wordt ${ }^{2}$ ) - het tijdvak van 1849-1865 wordt onbesproken gelaten - heb ik gemeend de bestaande leemte in de kennis van het Surinaamsch circulatiebankwezen te moeten aanvullen door mededeeling te doen van wat ter zake vóór 1865 is voorgevallen.

De eerste circulatiebank, welke in Suriname gewerkt

1) Nederlands twaalfde provincie.

$\left.{ }^{2}\right)$ Vgl. bladz. 23 en 36 van het Bankwezen in Nederlandsch-WestIndiē. 
heeft, was de ten gevolge van de bemoeiingen van den Commissaris-Generaal J. v. d. Bosch in 1829 te Paramaribo opgerichte Particuliere West-Indische Bank. Deze bank was - wat uit den naam niet viel af te leiden - eene zuivere Gouvernementsinstelling, welke hare gestie bepaalde tot Suriname. Reeds in 1831 moest zij hare werkzaamheden voor een goed deel stopzetten. Een aanzienlijk gedeelte harer middelen was vastgelegd geworden in langjarige hypotheken. Voorts was haar kapitaal, dat in het moederland moest berusten en waar tegenover in Suriname bankbiljetten zouden worden uitgegeven, nimmer bijeengebracht. De bank steunde zoodoende op het Opperbestuur in het moederland, dat ten gevolge van den Belgischen opstand in 1831 ophouden moest met het accepteeren van de door de instelling getrokken wissels.

Nog eenmaal van 1839-1842 hervatte de West-Indische Bank hare wisselafgiften en begon in verband daarmede hare circulatie uit te breiden. Weldra gingen de bankbiljetten deprecieeren en deden de wissels agio. Het gevolg was, dat de werkzaamheden van de bank opnieuw - en nu voor goed - werden stopgezet.

Bij Koninklijk besluit van 6 Februari 1847, Letter $\mathrm{O}^{5}$ (G. B. Bo. 4) werd bepaald, dat de bankbiljetten van de Particuliere West-Indische Bank vervangen zouden worden door Nederlandsche muntspeciën. 21 Maart 1848 trad de instelling in liquidatie. De afwikkeling liep allesbehalve vlug van stapel en werd eerst in 1870 beëindigd.

Van 1849 tot -zooals we hieronder zullen zien - 1865, was Suriname derhalve zonder circulatiebank en bijgevolg ook zonder eigen bankpapier. Een geluk was het voor de kolonie, dat de Ned. muntwet van 28 September 1816, Ned. Staatsblad No. 50, die sedert 1826 (G. B. No. 4) ook op Suriname van toepassing was, verviel door de wet van 26 November 1847 (Ned. Staatsblad No. 69). De wet van 1847 , die den zilveren standaard huldigde, werd op geheel West-Indië van toepassing verklaard (wet van 14 December 1853, Ned. Staatsblad No. 126). Deze wet, welke bij 
publicatie van 22 December 1854 (G. B. No. 12) in Suri name werd afgekondigd, machtigde 's Lands kassen tot aanneming van vreemde munten (o. a. Fransche 5 francsstukken, Mexicaansche dollars, Boliviaansche dollars, Noord-Amerikaansche dollars) tegen een vastgestelden koers. Door dezen maatregel werd de taak van de Nederlandsche Regeering om in de circulatie te voorzien aanmerkelijk verlicht.

Het eerste ontwerp voor eene Surinaamsche Bank was dat in 1862 van S. Abendanon Sz., ,exploiteur” te Paramaribo. Abendanon was getroffen door den min gunstigen toestand van landbouw, nijverheid en handel in zijne omgeving. Bij herhaalde bezoeken aan Demerara viel het hem op, dat de economische toestand in die Britsche kolonie veel beter was dan in Suriname. Hij schreef dit toe aan de aanwezigheid van twee flinke banken, de Colonial Bank en de British Bank of Guyana, terwijl in geheel Suriname geene enkele credietinstelling te vinden was. Als grondslag voor zijn ontwerp-octrooi had de voorsteller genomen de statuten van de beide banken uit Britsch-Guyana en het octrooi van De Javasche Bank (Ind. Staatsblad 1827, No. 111, zooals dat sedert gewijzigd was, het laatst in 1859 (Ind. Staatsblad No. 98)). De bank zouals naamlooze vennootschap te Paramaribo gevestigd worden en uitsluitend octrooi verkrijgen voor den tijd van 10 jaar. Het kapitaal zou aanvankelijk $f 2.000 .000$ bedragen, maar met toestemming van den Gouverneur tot $f 4.000 .000$ opgevoerd kunnen worden. De Bank mocht nimmer aan eenige onderneming deelnemen of roerende en onroerende goederen koopen. De bankbiljetten, welke wettig betaalmiddel zouden zijn, moesten minstens voor de helft door specie gedekt zijn. Het bestuur zou berusten bij een directeur en een secretaris onder toezicht van 6 commissarissen. In de commissie uit de deelhebbers der bank, belast met het onderzoek van de balans en de rekening en verantwoording, zou ook een vertegenwoordiger van het Gouvernement zitting nemen. $1 / \mathbf{4}_{\text {van }}$ de zuivere winst moest in het reservefonds gestort worden, totdat dit $25 \%$ van het gestort kapitaal zou bedragen. Tot directeur, se- 
cretaris of employé van de bank zou ook kunnen worden benoemd een koloniaal ambtenaar, die alsdan tijdelijk van zijn ambt zou worden ontheven.

Het ontwerp werd door den Gouverneur Van Lansberge (1859-1866) onderworpen aan het oordeel van de leden van den Kolonialen Raad en van een ambtenaar van de Administratie van Financiën. Enkele leden van den Kolonialen Raad meenden, dat de oprichting van eene circulatiebank in een leemte zou voorzien. De meesten waren niet zoo optimistisch. Zij wezen op den jammerlijke afloop van de Particuliere Bank voor West-Indië. Zij wilden eerst afwachten de afschaffing der slavernij in WestIndië en de regeling van de schadeloosstelling der eigenaren. Wellicht, merkten zij op, zou de kolonie dan zoo achteruitgegaan zijn, dat eene circulatiebank volkomen overbodig zou zijn. Eenige deelneming van belang in Suriname in de bank achtten zij onwaarschijnlijk.

In 1863 heeft Abendanon, die toentertijd sedert eenige maanden te Amsterdam verblijf hield, een gewijzigd ontwerp ingediend, blijkbaar onder den invloed van Amsterdamsche kooplieden. Het bestuur der bank te Paramaribo zou worden opgedragen aan een president, vier directeuren en een secretaris. De vier directeuren zouden jaarlijks aftreden, de president en de secretaris werden voor vast benoemd. Er zou een bijkantoor of vast agentschap te Amsterdam komen, bestuurd door een agent, benoemd door en onder toezicht van vijf commissarissen, die op hunne beurt gekozen werden door de stemgerechtigde aandeelhouders in Europa. 't Agentschap mocht uitsluitend in Europa voor de Bank handelen, maar was daarin ook geheel vrij. Tusschen de Bankdirectie en den agent moest elke 14 dagen uitwisseling van gegevens plaats hebben en voortdurende samenwerking bestaan.

De voornaamste grond voor de veranderingen was, zooals dadelijk voor den dag komt, eene poging om Amsterdamsch kapitaal voor de Bank te verkrijgen. In de Bijbank met hare geheel zelfstandige positie ligt al de kiem van de tegenwoordige Hoofddirectie.

Blijkbaar zijn de plannen van den heer Abendanon niet 
voor ernstig door de Regeering opgenomen, waarschijnlijk is hij er voorts niet in geslaagd het benoodigde kapitaal te vinden, want de Minister van Koloniën Fransen v. d. Putte (1863-1866) vond het niet noodig, er over advies uit te brengen aan de Kroon. Toch heeft de heer Abendanon zijn plan tot vestiging van eene circulatiebank in Suriname niet opgegeven. Het eerst heeft hij de Algemeene Maatschappij voor Handel en Nijverheid te Amsterdam weten te bewegen, voorstellen tot oprichting van eene Surinaamsche Bank in te dienen en toen de onderhandelingen ten slotte niet slaagden en de Maatschappij zich terugtrok, gaf hij den moed nog niet op en wist de Nederlandsche Crediet- en Depositokas, eveneens te Amsterdam, voor zijne plannen te winnen.

De Algemeene Maatschappij voor Handel en Nijverheid die in Juni 1863 met een plan kwam, om eene Surinaamsche Bank op te richten en daarvoor een octrooi van 50 jaren vroeg, was in April van dat jaar pas opgericht. Het kapitaal bedroeg $f$ 40.000.000. - waarvan $f$ 10.000.000.dadelijk gestort was; de gelden waren vooral bijeengebracht door Fransche en Belgische bankiers.

Toen, zooals wij hieronder zullen zien, de pogingen tot stichting van De Surinaamsche Bank niet spoedig vlotten, trok de Maatschappij zich terug en sloeg eene andere richting in. Nog in hetzelfde jaar (1863) richtte zij op de Nederlandsch Indische Handelsbank en de NederlandschIndische Spoorweg-Maatschappij, terwijl zij tot de oprichting van de Maatschappij tot Exploitatie van Staatsspoorwegen krachtig medewerkte. Door een en ander legde de Maatschappij haar kapitaal op te langen termijn vast. In 1868 moest zij ten slotte liquideeren.

De Algemeene Maatschappij vroeg tegelijk goedkeuring van de statuten der op te richten N. V. Surinaamsche Bank en goedkeuring van het Octrooi. Ze deed de toezegging het geheele kapitaal voor hare rekening te nemen. De Bank zou gevestigd zijn te Amsterdam en een Hoofd-Agentschap te Paramaribo hebben. Het kapitaal zou $f$ 4.000.000. - bedragen, waarvan $f$ 2.000.000 dadelijk te storten. Te Amsterdam zouden de zaken gedreven 
worden door 3 directeuren onder toezicht van 10 commissarissen, te Paramaribo door een Hoofdagentschap (een voorzitter en 2 leden).

Het Octrooi werd voor 50 jaar bij uitsluiting gevraagd. De Bank zou biljetten uitgeven van $f 2.50$ tot $f 1000$.en wel door middel van haar Hoofdagentschap. Deze bankbiljetten zouden in de kolonie wettig betaalmiddel zijn en moesten voor minstens $1 / 3$ door specie gedekt worden. De Bank mocht geen credieten in blanco verstrekken, geen gelden op hypotheek of scheepsverband geven, geen deel in ondernemingen nemen en geen goederen koopen.

In Augustus 1863 diende de Maatschappij een gewijzigd Octrooi in. Er werd nu octrooi gevraagd voor den tijd van 25 jaar in plaats van voor 50 jaar. De kleinste biljetten zouden $f 5$.- beloopen in stede van $f 2.50$. De hoedanigheid van wettig betaalmiddel werd niet meer voor de bankbiljetten gevorderd, maar wel werd gevraagd dat zij in betaling zouden worden aangenomen aan alle Gouvernementskassen in de kolonie. De Bank zou zonder provisie betalingen en ontvangsten doen voor het koloniaal bestuur.

Bij de Afdeeling West-Indische Zaken van het Departement van Koloniën had men nog al bezwaren tegen het gevraagde octrooi. Een tijdvak van 25 jaar kwam te lang voor, 10 jaar zou beter zijn. Biljetten van minder dan $f$ 10.- in omloop brengen verdiende geen aanbeveling. De voorgestelde dekking was onvoldoende; men wilde vrijheid van uitgifte geven tot een bepaald maximum. De boven dat bedrag uit te geven biljetten moesten ten volle door specie gedekt zijn. Toekenning van de hoedanigheid van wettig betaalmiddel aan de bankbiljetten, zooals eerst gevraagd was, scheen gevaarlijk. Beter zou 't zijn de biljetten in de Gouvernementskassen aan te nemen, zooals de Bank later voorstelde, maar slechts zoolang de Bank aan hare verplichtingen voldeed.

Aan enkele van deze bezwaren was door het gewijzigd ontwerp-octrooi al tegemoetgekomen. Blijkbaar was ondershands overleg gepleegd. 
Voorts werd te rade gegaan met den Minister van Financiën Betz en den President van De Nederlandsche Bank Mees. De Minister van Financiën vond vestiging van eene Surinaamsche Bank te Amsterdam met een agentschap in Suriname zeer oneigenaardig. Hij zag aankomen, dat dit agentschap of hoofdagentschap te veel gebonden zou zijn door de instructiën van de Directie. Hij was voorts bevreesd, dat De Surinaamsche Bank in strijd met de rechten van De Nederlandsche Bank hare biljetten ook in Nederland in omloop zou brengen. Suriname zou eenvoudig de brug zijn, waarover eene nieuwe circulatiebank naar Nederland werd overgebracht. Er zou dus moeten worden gewaakt tegen het tot stand komen onder den naam van Surinaamsche Bank van eene in Nederland werkende, biljetten uitgevende en inwisselende circulatiebank. Wilde eene circulatiebank aan gene zijde van den Oceaan gewenschte resultaten leveren, wilde zij een weldaad voor de regeering en de bevolking der kolonie kunnen heeten, dan diende hare gestie niet verdeeld te zijn, niet in Nederland te berusten, maar in Suriname zelf gevoerd te worden. Een voorbeeld kon veilig genomen worden aan het Octrooi en de Statuten van De Javasche Bank.

Mr. Mees, de president van De Nederlandsche Bank, achtte de vestiging te Amsterdam eveneens zonderling, maar meende er in te moeten berusten, omdat voor eene maatschappij uitsluitend in Suriname gevestigd geen geld te krijgen zou zijn. De bezwaren van Minister Betz achtte hij door aanvulling of wijziging van octrooi en statuten te ondervangen.

Verder werden nog verschillende opmerkingen gemaakt betreffende het gevraagde monopolie, de dekkingsvoorschriften, openbaarmaking van de weekbalans, staking van de betalingen in specie, toezicht door een Gouvernementscommissaris, enz.

Ten slotte werd besloten, dat ondershands met de $\mathrm{Al}$ gemeene Maatschappij voor Handel en Nijverheid in over leg zou worden getreden.

De tijd drong. Er was een ontwerp van wet tot vast- 
stelling van het Regeeringsreglement voor Suriname bij de Staten-Generaal aanhangig. Zoodra dit ontwerp wet zou zijn geworden en in werking getreden, zou bij koloniale verordening eene circulatiebank in Suriname kunnen worden opgericht ${ }^{\mathbf{1}}$ ). Men vreesde aan het Departement van Kolonien, dat in dat geval noch Amsterdamsch noch ander Europeesch kapitaal zich bij de instelling zou interesseeren.

In September 1863 trok de Algemeene Maatschappij van Handel en Nijverheid hare aanvraag om verleening van octrooi ten behoeve van eene op te richten Surinaamsche Bank in. Blijkbaar duurde de onderhandeling haar te lang en zag zij kans in eene andere richting met meer succes werkzaam te zijn.

De heer Abendanon zat echter niet stil. Aan zijn toedoen is het te danken, dat in Januari 1864 wederom een aanvraag om octrooi voor eene Surinaamsche Bank werd ingediend, thans door de Nederlandsche Crediet- en Depositobank te Amsterdam.

De Nederlandsche Crediet- en Deposito-Bank was even als de Algemeene Maatschappij voor Handel en Nijverheid in het Schwungjaar 1863 opgericht. Het initiatief tot de stichting werd genomen door Dr. S. Sarphati. Het kapitaal was groot $f$ 20.000.000.-, waarvan $f$ 10.000.000. geplaatst en $f$ 4.000.000.- gestort was. Een groot aandeel in de oprichting werd genomen door het Parijsche bankiershuis Bischofsheim. De aandeelen waren meest geplaatst in Frankrijk, België en Zwitserland en werden al spoedig in francs uitgedrukt. De Bank vestigde filialen te Parijs, Brussel, Antwerpen en Genève. Hoe langer hoe meer ging zij zich toeleggen op buitenlandsche leeningen. Haar bijkantoor te Parijs werd al spoedig veel belangrijker dan het hoofdkantoor te Amsterdam. In 1871 vereenigde de Bank zich ten slotte met de Banque de Paris tot de Banque de Paris et des Pays Bas, welke instelling thans nog agentschappen te Amsterdam en te Rotterdam

$\left.{ }^{1}\right)$ Cf. art. 164 van het „Reglement op het beleid der Regering in de kolonie Suriname" (Nederlandsch Staatsblad 1865, no. 55). 
heeft en op het gebied van internationale leeningen een eerste plaats inneemt.

Het voornemen van de Nederlandsche Crediet- en Deposito Bank om Nederlandsche ondernemingen te helpen oprichten, is slechts in beperkte mate verwezenlijkt; behalve De Surinaamsche Bank heeft zij alleen nog de Nederlandsche Bouwmaatschappij gesticht.

Het verzoek van de Nederlandsche Crediet- en Deposito Bank om octrooi gedurende 50 jaar voor eene op te richten Surinaamsche Bank was niet voor inwilliging vatbaar, omdat niet gelijktijdig ontwerp-statuten werden ingediend voor de te stichten naamlooze vennootschap.

Uit het zeer eenvoudig opgezette ontwerp-octrooi blijkt echter, dat de heer Abendanon zich de tegen het ontwerp van de Algemeene Maatschappij voor Handel en Nijverheid geopperde bedenkingen had ten nutte gemaakt. De werkkring van de Bank zou zich bepalen tot Suriname. Het kapitaal zou minstens $f$ 1.000.000.- groot zijn. Van het zijn van wettig betaalmiddel der bankbiljetten werd niet meer gerept. Alleen zouden de biljetten in de koloniale kassen als wettig betaalmiddel worden aangenomen. De kleinste coupure zou zijn $f$ 10.- De dekkingsverhouding werd aanvankelijk op $1 / 3$ vastgesteld, maar zou later bepaald worden door de Regeering, de Bankdirectie gehoord. De Regeering had de bevoegdheid de gepubliceerde balansen te vergelijken met de boeken en de bezittingen. De Bank zou zonder belooning werkzaam zijn als financieel agent en kassier van de Regeering in Suriname. Het octrooi zou vervallen, zoodra de Bank de voorschriften niet nakwam.

Nadat de Bank aan het verzoek om indiening der ontwerp-statuten voldaan had, werd het advies van den Minister van Financiën ingewonnen. Het oordeel van Minister Betz was veel gunstiger dan over het ontwerp van de Algemeene Maatschappij voor Handel en Nijverheid. Wel werd ook thans de oprichting van eene zelfstandige koloniale bank niet beoogd, daar de eigenlijke Directie in Nederland gevestigd bleef, doch dit was in verband met 
den toestand in Suriname onvermijdelijk. In de kolonie waren de elementen nog niet aanwezig om eene circulatiebank op te richten, zooals in Nederlandsch-Indië geschied was. Nu de werkkring van de Bank tot Suriname beperkt zou blijven, was het nadeel verbonden aan de verdeeling van het bankbeleid over Directie en Hoofdagentschap sterk verminderd.

Minister Betz had ten slotte bezwaar tegen de uitkeering van rente voor in rekening-courant gegeven gelden. Als Koninklijke Commissaris zou volgens hem kunnen optreden de Administrateur van Financiën of zijn plaatsvervanger.

In de voordracht aan de Koningin werd uiteengezet, dat de Ned. Bankwet van 22 December 1863 (Staatsblad No. 148), geen bezwaar opleverde voor de vestiging van eene Surinaamsche circulatiebank hier te lande. Voorts werd het wenschelijk verklaard, dat de kolonie zelf de krachten in zich bevatte om eene credietinstelling tot stand te brengen, maar aangezien Suriname geen bestanddeelen van eene zelfstandige maatschappij bezat was het noodzakelijk, althans vooreerst het bankwezen in de kolonie van hieruit te besturen. Minister Fransen v. d. Putte achtte het tijdverlies om op de totstandkoming van het nieuwe Regeeringsreglement te wachten. Het kwam hem beter voor niet te spreken van een Directie te Amsterdam en een Hoofd-Agentschap te Paramaribo, maar van eene Hoofddirectie te Amsterdam en eene Directie te Paramaribo, om zoodoende het denkbeeld van afhankelijkheid niet te zeer te doen uitkomen. Zoowel wisselhandel als het nemen van deposito's met rentevergoeding moest toegelaten worden.

Alvorens het ontwerp - zij het ook met eenige wijzigingen - goed te keuren, had Minister Fransen v. d. Putte nog advies gevraagd aan Mr. W. C. Mees, president van De Nederlandsche Bank, en Jhr. C. A. van Sypesteyn, toenmaals chef van de West-Indische afdeeling van het Departement van Koloniën, later van 1873-1882 Gouverneur van Suriname.

Mr. Mees vond een te Amsterdam gevestigde Bank, 
wier werkkring zich bepaalt tot Suriname, nog altijd eene zonderlinge inrichting. Hij zag echter in, dat eene zelfstandige Surinaamsche Bank voorshands niet te verwezenlijken was. Vestiging van filialen te Nickerie en op de West-Indische eilanden wilde hij mogelijk maken. Mr. Mees had geen bezwaar om aan de Bank wisselhandel en rentevergoeding voor deposito's te veroorloven. „Een dorpswinkel moet dikwijls kruidenierswaren en manufacturen voorhanden hebben. Zoo zal ook de Surinaamsche (circulatie) bank meer moeten omvatten dan een biljettenbank in eene Europeesche hoofdstad".

Jhr. van Sypesteyn betreurde het, dat een Bank in Suriname al niet tot stand gekomen was; eene dergelijke instelling zou goede diensten hebben kunnen verrichten, om de wegvloeiing van het geld na de opheffing van de slavernij (1 Januari 1863) tegen te gaan. Hij wees er op, dat van de ontwerpen van Abendanon en de Algemeene Maatschappij voor Handel en Nijverheid niets gekomen was en drong verder met kracht er op aan de aanvrage van de Nederlandsche Crediet- en Deposito Bank zonder vertraging af te doen. Deed men dit niet, dan vreesde hij, dat men ten slotte geen Europeesch kapitaal zou vinden, dat zich in Suriname zou willen wagen. Hij achtte het overbodig het advies van den Gouverneur van Suriname te vragen.

De Minister Fransen v. d. Putte beantwoordde de gemaakte bedenkingen en handhaafde, op enkele ondergeschikte punten toegevende, in hoofdzaak zijn standpunt.

Bij Koninklijk besluit van 19 Mei 1864, No. 30, kwam eindelijk het eerste Octrooi van De Surinaamsche Bank tot stand.

Bij dit Octrooi (G. B. 1864, No. 14) kreeg De Surinaamsche Bank het recht om gedurende 25 jaar als circulatiebank in de kolonie Suriname te mogen optreden. Aan geene enkele andere bankinstelling zouden meer voorrechten worden verleend. De werkzaamheden van de Bank zouden zich bepalen tot de kolonie Suriname, waar 
de Directie te Paramaribo zou werken onder leiding van de Hoofddirectie te Amsterdam. De Bank mocht hare bankbiljetten niet in omloop brengen in het Rijk of in de andere koloniën.

Het kapitaal bedroeg $f 1.000 .000$. - ten volle gestort. De werkzaamheden van de Hoofddirectie bestonden o. m. in het geven van instructiën aan de Directie, het ontvangen en verzenden van landsmunt, het koopen en verkoopen, ontvangen en verzenden van specie, het accepteeren, betalen en afgeven van wissels, incasseering van wissels, beleggen van kassaldi in beleeningen, prolongatiën, enz.

Tot het terrein van de Directie te Paramaribo behoorde o. a. het disconteeren van wisselbrieven, het koopen en verkoopen van wissels, het beleenen van goederen, het handelen in goud en zilver, het ontvangen van gelden in rekening-courant, het uitvoeren van financieele commissies voor het Gouvernement en voor particulieren. De Bank mocht geen crediet in blanco verstrekken, niet deelnemen aan ondernemingen, geen eigen aandeelen inkoopen, geen goederen, waren, enz. koopen, geen hypotheek nemen of gelden op scheepsverband uitzetten.

De helft van haar kapitaal en haar reservefonds mocht de Bank beleggen in NederlandscheStaatsschuld en pandbrieven van hypotheekbanken.

De bankbiljetten mochten tot geen lager bedrag worden uitgegeven dan $f$ 10.- . $\mathrm{Zij}$ waren dagelijks tegen gangbare specie inwisselbaar bij de Bank te Paramaribo. Zij konden als betaalmiddel in de Gouvernementskassen der kolonie worden toegelaten.

Het dekkingspercentage voor bankbiljetten, rekeningcourantsaldi, enz. zou worden bepaald bij K. B. op voorstel van de Hoofddirectie. De Gouverneur kon het percentage in dringende omstandigheden op voordracht van de Directie te Paramaribo onder nadere Koninklijke goedkeuring tijdelijk wijzigen.

Aanvankelijk werd bepaald, dat de bankbiljetten en de dadelijk opeischbare vorderingen voor $1 / 3$ door specie 
gedekt moesten zijn en dat boven de $f 3.000 .000$ - de genoemde biljetten en vorderingen ten volle door standaardmunt of muntmateriaal gewaarborgd moesten zijn. Over ontvangsten en uitbetalingen voor de kolonie zou de Barik geen provisie berekenen. De Hoofddirectie zou bestaan uit 2 leden. Toezicht zou uitgeoefend worden door 6 Commissarissen. De Directie te Paramaribo zou gevormd worden door een voorzitter en twee leden.In plaats van door Commissarissen zou hier toezicht uitgeoefend worden door eene Commissie. Van Regeeringswege werd toezicht gehouden op de Directie te Paramaribo door een Gouvernements-Commissaris.

Aan den Gouverneur van Suriname werd nu een afschrift van het K. B., waarbij het octrooi werd vastgesteld, aangeboden, met verzoek om afkondiging en uitvoering.

Tevens werd een en ander van de voorgeschiedenis medegedeeld. De Gouverneur zal zonder twijfel wel verbaasd geweest zijn, toen hij vernam, dat zonder voorafgaande raadpleging met hem de koloniale circulatiebank tot stand was gekomen.

Haasten deed de nieuwe Bank zich niet. Eerst in October 1864 kwam het verzoek om Koninklijke goedkeuring der ontwerp-statuten. De goedkeuring volgde bij Koninklijk besluit van 9 November 1864, No. 65. In Februari 1865 werden de statuten notarieel verleden en in de Staatscourant (Nos. 42 t/m 44) openbaar gemaakt.

Tot leden van de Hoofddirectie werden benoemd de Amsterdamsche reeder en koopman Ch. M. Fraissinet en de later zoo bekend geworden econoom N. G. Pierson. Deze benoeming werd goedgekeurd bij Koninklijk besluit van 10 Februari 1865, No. 52.

Vervolgens had de benoeming van de Directieleden te Paramaribo plaats. Tot Directeur-Voorzitter werd aangewezen H. G. C. Muller, tot Directeur W. E. Ruhmann en tot Directeur-Secretaris S. Abendanon Sz., de man aan wiens ijverige propaganda de stichting van De Surinaamsche Bank feitelijk te danken is. De benoemingen 
322 POGINGEN TOT OPRICHTING EENER CIRCULATIEBANK

werden goedgekeurd bij het Koninklijk besluit van 4 Maart 1865, No. 29.

Onder de Commissarissen treffen we o.a. aan Dr. S. Sarphati en A. C. Wertheim. De eerste was de stichter van de Nederlandsche Crediet- en Depositokas, de laatste werd later een van de meestbekende bankiers uit ons land. Tot Gouvernements-Commissaris bij de bank in Suriname werd benoemd de Administrateur van Financiën Mr. C. H. Immerzeel. 